\title{
NATIONALISM AND ISLAM IN RELIGIOUS LEARNING: OPTIMIZATION OF INSAN KAMIL CHARACTER BUILDING
}

\author{
Yulia Rahman ${ }^{1 *}$ A. Rahman Ritonga ${ }^{2}$ \\ ${ }^{1}$ Intitut Agama Islam Negeri (LAIN) Bukittinggi, Indonesia, email: yuliarabman@iainbukittinggi.ac.id \\ ${ }^{2}$ Institut Agama Islam Negeri (LAIN) Bukittinggi, Indonesia, email: rabmanritonga57@gmail.com \\ *Corresponding Author \\ (c) (i) (2) \\ C2021 by the authors. Submitted for possible open access publication under the terms and conditions of the Creative Commons \\ Attribution-ShareAlike 4.0 International License-(CC-BY-SA) (https://creativecommons.org/licenses/by-sa/4.0/) \\ doi DOI http://dx.doi.org/10.30983/islam realitas.v7i1.4517 \\ Submission: 4 January $2021 \quad$ Revised: 25 August $2021 \quad$ Published: 31 August 2021
}

\begin{abstract}
This study aims to explain that religious learning held in public schools is able to instill the values of nationalism and Islam, thus forming the character of students of insan kamil. This theory refutes the opinion which states that religious education creates civic conflict and cannot be a complement to civic education. This research complements several previous studies by adding research on Rohis (spiritual learning program) as part of religious learning in public schools. The research method used is a mix-method research with qualitative analysis and a sociological approach. The conclusion of this study is that religious learning, both in terms of material and methodology, is able to instill the value of religiousnationalism. The internalization of the values of nationalism-religion is applied in PAI (Islamic) learning in the classroom which is guided by teachers, and religious learning in Rohis which is guided by mentors.
\end{abstract}

Keywords: Nationalism, Religious Learning, Character of Insan Kamil

\section{Abstrak}

Penelitian ini bertujuan untuk menjelaskan bahwa pembelajaran agama yang diselenggarakan di sekolah umum mampu menanamkan nilai-nilai nasionalisme dan Islam, sebingga membentuk karakter peserta didik yang insan kamil. Teori ini membantah pendapat yang menyatakan bahwa pendidikan agama berpotensi melabirkan konflik kewarganegaraan dan tidak mampu menjadi komplemen pendidikan kewarganegaraan. Penelitian ini melengkapi beberapa penelitian terdabulu dengan menambabkan penelitian pada pembelajaran Rohis sebagai bagian dari pembelajaran agama di sekolah umum. Metode penelitian yang digunakan adalab mix-method research dengan analisis kualitatif dan pendekatan sosiologi pendidikan. Kesimpulan penelitian ini adalah bahwa pembelajaran agama, baik dari segi materi dan metodologinya mampu menanamkan nilai nasionalisme-religius. Internalisasi nilai nasionalisme-religius ini diterapkan dalam pembelajaran PAI di kelas yang dibimbing oleh guru dan pembelajaran agama di Rohis yang dibimbing oleh para mentor.

Kata Kunci: Nasionalisme, Pembelajaran Agama, Karakter Insan Kamil

\section{Background}

Religious education in Indonesia takes place as a strategic position for character building model. This material has become a role model in public schools to realize the function of national education in the National Education System Law no. 20 of 2003 in chapter II article 3 as a forum for the formation of dignified national character and civilization, educating the nation, as well as developing the character of faith, taqwa, noble character and becoming a democratic and responsible citizen. ${ }^{1}$ In addition, in the GBPP Islamic Religious Education in Senior High Schools it is explained that PAI is a conscious effort to prepare students to believe, understand, appreciate and practice Islam through guidance, teaching, and/or training activities by paying attention to the demands to respect other religions in relationships of interreligious harmony in society to realize national

1 Tim Departemen Pendidikan Nasional, UndangUndang Sistem Pendidikan Nasional No. 20 Tabun 2003 (Jakarta: Departemen Pendidikan Nasional, 2003), p. 4. 
unity. $^{2}$

The government's commitment in designing religious education as the basis for the formation of national character is the hope of Muslims for the realization of a harmonious relationship between the values of nationalism and Islam. This concept contradicts some of the arguments of observers and researchers outside Indonesia. Among them is Hargreaves' opinion which concludes that in order to create a harmonious life between a pluralistic society, religious education must be abolished from schools. He revealed that religious education has a moral purpose, whereas among a pluralistic society there should be no consensus between religion and morals. Therefore, religious education should be replaced with citizenship education. ${ }^{3}$ This opinion is in line with what was expressed by Balycock that there is a distance and barrier between religious education and citizenship education. ${ }^{4}$ This is contrary to Grimmit's opinion which states that citizenship education is a direct threat to religious education that has the potential to damage the contribution of religion that is being built.. ${ }^{5}$ This kind of concern arises along with the revitalization of civic education as a forum for fostering democratic character which is believed to be able to bring about world peace.

The debate on the above topics shows the relationship between religious values and citizenship which is less harmonious in various parts of the world. However, in Indonesia, the

2 Team, GBPP Pendidikan Agama Islam (Jakarta: Depag, 1994), p. 1.

${ }^{3}$ David Hargreaves, The Mosaic of Learning: Schools and Teachers for the Next Century (London: Demos, 1994), p. 27-30.

4 L. Blaycock, Secondary Religion Education and Citizenship: Towards an Open Frontier (Birmingham: Christian Education Publications, 2002), p. 2.

5 M. Grimmitt, Pedagogies of Religious Education (Great Wakering: McCrimmon, 2000), p.11.

6 Agil Nanggala, 'Citizenship Education as a Democracy Learning for Students in Higher Education', Intrenational Journal of Education and Curriculum Application, 3.1 (2020), 69-80. relationship between religion and the state has long been very well established with the agreement of a pluralistic Indonesian society to accept Pancasila as a way of life, a source of law and the basis of the state. The ideology of Pancasila which is included in the education is also a form of state control over education. This happens a lot in some countries that are still influenced by capitalist ideology. Sirozi argues that in countries that implement a capitalist economic system, education plays an important role as a medium for achieving state goals. ${ }^{7}$ From this it can be said that the cultivation and spread of an ideology is no longer limited to politics or economics, but also in the domain of education.

Therefore, the world of education in Indonesia seeks to make religious education complementary to civic education with the same goal, namely to form the students' characters to be noble and beneficial to the nation and state. The same understanding is also expressed by Jackson that religious education has a big role to develop civic education. This is exemplified by the contribution of religion in creating the concept of ethnicity, community and nationality. ${ }^{8}$ Halstead further explained that religious education has a complex relationship with citizenship, even having the same opportunities as citizenship education in instilling moral values, such as tolerance, respect, love, commitment, trust, minorities and others.? Guitierrez even mentioned that civic education

7 Muhammad Sirozi, Politik Pendidikan: Dinamika Hubungan Antara Kepentingan Kekuasaan dan Praktik Penyelenggaraan Pendidikan (Jakarta: Raja Grafindo Persada, 2007), p. 12.

8 Robert Jackson, 'Citizenship as Replacement for Religious Education or Religious Education as Complementary to Citizenship Education', in International Perspective on Citizenship, Education and Religion Diversity, ed. by Robert Jackson (London: Routledge Falmer, 2003), p. 67.

9 J. Mark Halstead dan Mark A, Citizenship and

Moral Education (New Yorkhttps://jamba.org.za/index.php/jamba/article/vie w/1020/2047: Routledge, 2006), p.104. 
requires a spiritual foundation that comes from religion, because religion has a high moral motivation value for its adherents, even in a country that adheres to secularism between religion and the state. ${ }^{10}$

Based on the arguments above, this study aims to examine the trend of religious learning on the values of nationalism and Islamic values. This research is a case study at SMAN 8 Jakarta, especially in PAI subjects and the Rohis organization in 2011. The implementation of this research 10 years ago is expected to provide an overview of the conditions of religious learning in PAI and Rohis so that it can be compared with the conditions of learning in the past. now. The research is focused on looking at the trend of material content and the application of learning methods in PAI classes and the mentoring activities of the Rohis group. The methodology used is a mix-method research with qualitative analysis and an educational sociology approach. ${ }^{11}$ Data collecting is using interview techniques with PAI teachers and Rohis mentors, documentation and questionnaires distributed to 91 students and 25 students involved in Rohis activities. ${ }^{12}$ Through this methodology, this research is expected to reveal the contribution of PAI learning and the mentoring of Rohis in internalizing the values of nationalism and Islam to students.

\section{Islamic Religious Learning: Between Nationalism and Islamism}

Learning is a process to modify cognitive and behavioral domains, and can be understood as a function of various communication processes involving teacher, student, subject, learning strategies and

\footnotetext{
10 Robert Gutierez, 'Spiritual Foundation for Civic Education', Taboo, 9.1 (2005), p. 69.

${ }^{11}$ Lexy J. Moleong, Metodologi Penelitian Kualitatif (Bandung: Remaja Rosdakarya, 2000), p. 8-11.

12 Suharsimi Arikunto, Prosedur Penelitian: Suatu Pendekatan Praktik (Jakarta: Rineka Cipta, 2006), p. 231.
}

evaluation factors. ${ }^{13}$ Learning practices in this definition are also applied in various types of education, including Islamic religious education. Islamic Religious Education as a subject emphasizes more aspects of values, both divine values and human values. This value is then instilled in students to build a character that is attached to their personality. Therefore, the educational strategy in Islam is classified into five stages; first, the indoctrination stage which aims to instill new ideas that are considered good and correct with an emotional approach and exemplary. Second, moral reasoning begins with the stage of presenting contradictory moral dilemmas, conducting group discussions, until obtaining clarification of the selected values. Third, predict the consequences that will occur from the selection and application of a certain value system. Fourth, clarification techniques to help children determine the selected values, and fifth, internalization techniques to instill these values in the child's personality so that it becomes a strong character. ${ }^{14}$

The purpose of PAI subjects as the key of character building requires detailed and complex implementation. But this is precisely the main problem and has not been resolved until now. The allocation of PAI learning time that is so short, makes the space for character formation increasingly narrow. Therefore, Islamic religious learning begins to be developed in extracurricular activities outside of school hours. One of the extracurricular activities active in Islamic religious learning is Rohani Islam (Rohis).

Among schools during the New Order, many religious organizations were banned from their activities, and the only organization allowed was the Student Intra-School

13 Julia Overton Healy, 'Learning Enhancement', in Learning and Teaching, ed. by Joseph Zajda (Australia: James Nicholas Publisher, 2006), p. 1.

14 Muhaimin, Paradigma Pendidikan Islam: Upaya Mengefektifkan PAI di Sekolah (Bandung: Remaja Rosdakarya, 2004), p. 236. 
Organization (OSIS). But like the general organization, OSIS is also equipped with various departments, including a religious department called Rohis. ${ }^{15}$ Rohis' activities were limited to religious culture that was engaged in organizing religious activities such as celebrating Islamic holidays, and still far from ideological. Until the decade of the $90 \mathrm{~s}$, Rohis began to metamorphose into a movement that tends to be ideological, especially when Rohis had almost the same position as OSIS in public schools in the 2000s. ${ }^{16}$ Furthermore, Rohis eventually became a driving force in the process of "Islamization" of schools through school da'wah activities. In general, these da'wah activities were oriented to the concept of tarbiyah which usually functioned as regeneration among the Ikhwan al-Muslimin. ${ }^{17}$

Based on this concept, Rohis focusee its da'wah activities by carrying out various da'wah methods in schools through three stages; a) Pre-Student Orientation, which new student members were recruited during this stage, b) Student Orientation, by collecting students data, communicative mentoring, wall magazine exhibitions, brochures and bazaars, and c) Post-Student Orientation, by da'wah 'ammah or syi'ar to teach Islamic thought to students, through mentoring activities, lectures, counseling on adolescent problems, Islamic studies, rituals, arts, sports and so on. ${ }^{18}$ Among these various activities, mentoring is the most prominent because of its routine and consistent implementation.

Spiritual Mentoring is a form of recruitment that tends to be applicable, flexible, sociable and tolerant in accordance

15 Farha Ciciek, Kaum Muda dan Regenerasi' Gerakan Fundamentalis di Indonesia (Jakarta: Laporam Penelitian Rahima, 2008), p. 4.

${ }^{16}$ Farha Ciciek.

17 Utsman 'Abd al-Mu'iz Ruslan, Tarbiyah Siyasiyah: Pendidikan Politik Ikhwanul Muslimin, ed. by Saifuddin Abu Sayyid (Solo: Era Intermedia, 2000), p. 483.

${ }^{18}$ Farha Ciciek. with da'wah nuances of the tarbiyah movement's. ${ }^{19}$ Another thing that characterizes this mentoring activity is the involvement of Rohis alumni in public schools who then remain active in campus da'wah. They return to help with various Rohis activities at the school level. However, this does not mean that schools neglect to control every da'wah activity within the Rohis. The school provides Rohis mentor teachers to keep control of every material and activity on the agenda, even though in reality, Rohis members prefer activities with mentors over mentor teachers. This unique condition and atmosphere of Rohis learning turned out to be the ground for the regeneration of several Islamic movements that were opposed by the state, such as Hizb ut-Tahrir Indonesia and the Islamic State of Indonesia. ${ }^{20}$

In its development, Rohis experienced the dynamics of tendencies which were influenced by the external thought of the school. These influences finally give the impression that there are seeds of radicalization in the activities of Rohis. This is as stated in the research of the Research and Development of Religion Semarang that conceptually the Rohis at the high school level is the organization that plays the most role in regeneration to form militancy which leads to a political orientation. From the aspect of tolerance, Rohis is considered to have two types of tolerance, namely exclusive and inclusive. Although the more prominent feature is exclusivism towards people of other religions. ${ }^{21}$

The description of the two types of Islamic religious learning above shows that on

19 Yon Machmudi, Partai Keadilan Sejabtera: Wajab Baru Islam Politike Indonesia (Bandung: Harakatuna Publishing, 2005), p. 40.

${ }^{20}$ Farha Ciciek.

21 Balitbang Agama Semarang, Transmisi NilaiNilai Keagamaan Melalui Organisasi Rohis (Orientasi Politik dan Sikap Toleransi Peserta Didik) (Semarang: Balitbang Agama, 2017), p. 23. 
one hand the learning has a noble goal, namely to form a comprehensive character of students in accordance with the mandate of Pancasila and the 1945 Constitution. But on the other hand, PAI and Rohis become an easy ground for planting ideologies which are not in line with the guidelines of the life of the nation and the state. So the interesting thing to study is how religious learning responds to the ideology of nationalism and Islamic teachings in order to achieve the goal of forming noble character.

In the world of education, the issue of nationalism usually arises when there is a debate about the historical content or syllabus literature. However, when it is at the level of discussion about the contribution of learning materials that lead to national awareness, the world of education is firm and clear. For example, the rise of the theory of multiculturalism which shows the friendly face of nationalism and its relevance to education. ${ }^{22}$ The goal, according to Wiggin, is so that the world of education can instill a sense of love for the nation and belief in religion at the same time. ${ }^{23}$ Students should be introduced and accustomed to understanding and living the values of humanity and love of the nation so that they become core values or living values rooted in religious teachings and the noble heritage of the nation. These values are consistently instilled to become part of the school culture. ${ }^{24}$

Among the values of nationalism that need to be internalized in Islamic religious learning both in PAI and Rohis are the cultivation of multiculturalism, Pancasila values such as diversity and religious diversity, justice and humanity, unity and equality, harmony and

22 Christoper Winch dan John GIngell, Philosophy of Education: The Key Concepts, 2nd edn (New York: Routledge, 2008), p. 142.

${ }^{23}$ Gladys A. Wiggin, Education and Nationalism: An Historical Interpretation at American Education (New York: McGraw-Hill Book Company Inc., 1962), p.13-21.

${ }^{24}$ M. Sukardjo dan Ukim Komaruddin, Landasan Pendidikan: Konsep dan Aplikasinya (Jakarta: Rajawali Press, 2009), p. 76-77 tolerance, and love for the homeland. ${ }^{25}$ All of these values basically do not conflict with the teachings of Islam.

Islam, as a teaching rooted in God's revelation, is different from other ideologies which are not rooted in theology. However, when the word Islam is understood as "Islamism" it will carry the meaning as an Islamic political movement. During the Orde Lama era, this Islamic political movement was represented by Darul Islam/Indonesian Islamic Army (DI/TII) which involved Masjumi, PSI and so on. Meanwhile, during the Orde Baru era, this political movement had touched students represented by the Indonesian Islamic Students (PII) and the Islamic Student Association (HMI). Until the end of the Orde Baru, there were several Islamic groups who tried to change the pattern of Islamic political movements into da'wah, education and pesantren movements. ${ }^{26}$ In this package, Islamism is spread through the process of recruitment of the younger generation, in which in its development, there are two patterns that dominate the materials and methods of learning and da'wah, namely fundamentalism and radicalism.

\section{Islamic Religious Learning Materials: Between Nationalism and Islam}

The composing of religious learning materials in PAI subjects refers to the National Education System Law no. 20 of 2003, and aims to strive for the achievement of national goals in forming Muslim individuals and citizens with noble character. In the distribution of PAI learning materials there are several aspects that are studied, namely; aspects of the Quran, aspects of faith, aspects of

25 Arief Furchan, Developing Pancasilaist Muslims: Islamic Religious Education in Public Schools in Indonesia (Jakarta: Logos Wacana Ilmu, 2002), p. 174.

${ }^{26}$ S. Kirbiantoro dan Dody Rudianto, Pergulatan Ideologi Partai Politik Indonesia: Nasionalisme, Islamisme, Komunisme dan Militerisme (Jakarta: Badan Politik Pertahanan dan Keamanan Dewan Pimpinan Pusat PAN, 2006), p. 45. 
morality, aspects of Islamic law and aspects of Islamic history. The reinforcement of these materials can also be found in spiritual learning. The material discussed in Rohis includes faith, worship and social material. The hallmark of Rohis' material is actual socialcommunity issues, because according to Rohis' mentor, discussions that are limited to the topic of ibadah mabdhah will be boring and hinder Rohis' function as an extracurricular member. While the material on morals is developed through the absorption of the historical wisdom of the prophets and companions and then associated with current events. $^{27}$

\section{State and Religion in Islamic Religious Learning}

The orientation of religious learning that examines and sees the harmonization of the relationship between state and religion is an important step in efforts to internalize religious-nationalism values in students. In PAI learning materials, this is represented by themes such as; a) love for the homeland, ${ }^{28}$ b) b) acceptance of the plurality of nations, ${ }^{29}$ c) c) harmonious relations between religion and the state. $^{30}$ These themes are then taught in the material aspects of PAI.

In the aspect of Al-Quran learning material, the love for the homeland that is instilled is universal, namely protecting and preserving the earth wherever they are, not only in the homeland. The emphasis on love for the homeland is still found in the opening of the material on the Qur'anic verse about

27 Informan A, (Rohis Mentor) Interview, \{Wednesday, 14 August 2011\}.

28 Anthony D. Smith, Nasionalisme: Teori, Ideologi, Sejaran (Jakarta: Erlangga, 2003), p.43.

29 H.A.R. Tilaar, Multikulturalisme: TantanganTantangan Global Masa Depan dalam Transformasi Pendidikan Nasional, (Jakarta: PT Grasindo, 2004), p. 195.

${ }^{30}$ Bahtiar Effendy, Islam dan Negara: Transformasi Pemikiran dan Praktik Politik Islam di Indonesia (Jakarta: Paramadina, 1998), p. 80. preserving the environment. While acceptance of the plurality of nations is clearly expressed in the material, complemented by the motivation to respect each other, not only in the context of religious and cultural differences, but also to differences that occur between fellow Muslims, such as differences of opinion and religious color. The discussion about plurality is not directed to the meaning of pluralism which tends to give the wrong concept about equalizing the creed of all religions. The discussion about the harmonious relationship between religion and the state has not been clearly explained in the PAI learning materials, because the discourse tends to lead to a political level so that it is considered not relevant to be studied in secondary schools.

In the aspect of aqidah, indicators of nationalism have not spread to all materials, such as faith in angels and the books of Allah. However, learning material that is integrative with the value of nationalism can be done by looking at the relationship of monotheism as a source of faith with the social life of the community. The steps that can be taken are to use the proclamation or declaration of life guided by the Qur'an, then translate it into a cultural attitude to develop good deeds. ${ }^{3}$

As for the moral aspect, it is the most potential aspect to grow the value of nationalism, because its application in the form of behavior is easier to identify and does not require much in-depth interpretation. The internalization of religious nationalism values is contained in the themes of etiquette towards the environment, willingness to sacrifice, friendship, unity and integrity, tolerance, antidiscrimination, avoiding hostility, prohibition of running away from battle, loving the nation's cultural works and agreeing on national rules and norms.

31 M. Amien Rais, Taubid Sosial; Formula Menggempur Kesenjangan (Bandung: Mizan, 1998), p. 37-43. 
In the aspect of Islamic law, an indicator that can be identified is the growing sense of unity that is not only found in social services such as zakat, hajj and muamalah, but also in prayer. The unity that is built is indeed more referring to ukhuwah Islamiyah (Islamic brotherhood), but the existence of material that links the functions and benefits of zakat with state taxes can represent the meaning of ukhuwah wathaniyah (national brotherhood). Islamic law education through PAI covers two areas, namely worship and muamalah. This classification categorizes the human relationship with God in carrying out the obligations of a Muslim as a law of worship, while God's provisions are directly related to social life and are open to be developed through ijtihad as muamalah law. The PAI material also refers to this categorization, so that the development of nationalism in the legal aspect of muamalah can be identified easily and clearly. Even so, the purpose of the law of worship is not limited to transcendent values, but also develops the social personality of students. This is reflected in the themes of the wisdom of prayer, the wisdom of zakat, the pilgrimage and paying taxes.

Based on these findings, it can be concluded that the harmonious relationship between religion and the state as a form of religious-nationalism is taught and discussed in PAI learning materials in a broad sense and apart from the narrow meaning which assumes that nationalism will only lead to chauvinism. In the research conducted by Mukhlisin, it was found that at present the nationalism is one of the main characters that has the potential to grow and develop through PAI learning, including tolerance, democracy, national spirit, love for the homeland, communicative, peaceloving, social and environmental care. ${ }^{32}$

32 M. Nurul Mukhlisin, 'Pengembangan PAI Berbasis Pendidikan Karakter', Inovatif, 1.2 (2015), 3856.
In contrast to PAI, the learning materials among Rohis at the secondary school level have not yet reached the stage of national or state issues. The dominant topic in the study of Rohis is still focused on the basis for the formation and strengthening of the Muslim personality. The consideration is the urgency of the delivery of the Rohis da'wah itself, given the age of the Rohis members who are considered not ready to accept such materials. They will be more receptive to material about strengthening their faith and personality. However, Rohis' mentor did not deny the possibility of material being developed in the realm of nation and state issues if Rohis members were deemed ready to accept the theme, usually when they were already at the university level. ${ }^{33}$

On the other hand, the themes discussed in Rohis reflect an acceptance of the plurality and heterogeneity of Rohis members. The Rohis coach revealed that in dealing with differences and diversity in their society, Rohis members are more inclusive. Including in responding to the use of jilbab, the Rohis group explicitly stated their willingness to accept members regardless of their clothing differences. Likewise, the attitude of the Rohis in fostering a sense of unity and brotherhood. This effort is developed through taking lessons from religious materials, and violations of the value of unity are considered as violations of religion. Rohis' mentor also stated that there is still great potential in Rohis' activities to maximize his vision and mission in character building not only as Muslims, but also as citizens. $^{34}$

At this point, it can be understood that PAI and Rohis do not contradict each other in understanding the value of nationalism through Islamic teachings. Rohis provides

\footnotetext{
33 Informan A, (Rohis Mentor) Interview, \{Wednesday, 14 August 2011\}.

34 Informan B, (Rohis Mentor) Interview, \{Wednesday, 14 August 2011\}.
} 
support in developing a culture of unity or ukhuwah and acceptance of plurality. In other words, the studies discussed in Rohis have led to indicators of tolerance. This proves that the period of intolerance in Rohis has ended. The results of Maknun's research revealed that in the pre-2010 period, Rohis was more concerned with alumni networks affiliated with an intolerant ideology indicated by apathy towards groups outside of his understanding. After 2010, awareness began to emerge about the importance of mentoring and supervising Rohis activities so that spiritual learning tends to be neutral and moderate. ${ }^{35}$

However, on the other hand, PAI must stand alone - without Rohis - in an effort to instill a sense of love for the homeland and insight into the relationship between religion and the state. This does not mean that Rohis tends to instill the values of Islamism. Because Rohis prefers to avoid issues of politics which makes it less likely that the issue of an Islamic state and the institutionalization of Islamic sharia is studied in the student organization. Research conducted by Az Zafi states that basically Rohis has a contribution to form an attitude of nationalism, unity by relying on verbal and non-verbal communication, as well as good cooperation and interaction between Rohis and PAI teachers at school. ${ }^{36}$ Through these efforts, Rohis is expected to remain an important part of realizing ukhuwah wathaniyah, ukhuwah insaniyah and ukhuwah Islamiyah.

\section{Pancasila and Al-Quran in Islamic Religious Learning}

Religious learning materials, in carrying out their functions as character-building agents in public schools, should present materials that

35 Moch. Lukluil Maknun dkk, Literatur Keagamaan Rohis dan Wacana Intoleransi, I (Jakarta Pusat: Litbangdiklat Press, 2018), p. 20.

36 Ashif Az Zafi, Nilai Nasionalisme Kebangsaan Aktivis Rohis', Belajea: Jurnal Pendidikan Islam, 2.2 (2019), 165-84. support the harmonization of Pancasila and the Quran. This function can be viewed from the perspective indicator that the value of Pancasila is in accordance with the Qur'an and can be accepted as; first, the way of life, ${ }^{37}$ second, the source of state law, and third, as the basis for human values, democracy and justice. ${ }^{38}$ The three indicators are fused in various aspects of PAI learning materials.

In the aspect of learning the Quran, the explanation that Pancasila and the Quran both function as a way of life is rarely associated. However, in general, PAI's material is more inclined to the opinion that believes that democracy, humanity and justice do not conflict with the principles of the Qur'an. Human values in particular, such as human duties as caliphs, supporting the poor, get a dominant portion in the presentation of material by referring to the content of the AlQuran, and have not touched on its relation to Pancasila. This is understandable because the purpose of learning aspects of the Qur'an is to strengthen the role of the Qur'an itself in the souls of students.

In the aspect of faith, the portion of nationalism indicators is still in a minimal size, namely in the form of acceptance of Pancasila as a guide to state life. In more detail, there is an explanation that Pancasila can guarantee freedom of religion and carry out its teachings in the life of a state with a pluralistic society. Meanwhile, in the aspect of Islamic law, the harmonization of Pancasila and the Qur'an as a source of law is manifested in the 'urf material which is sourced from ijtiihad. Although ijtihad does not mean Pancasila or state legislation directly, it does contain the meaning of

37 M. Abdul Karim, Menggali Muatan Pancasila dalam Perspektif Islam (Yogyakarta: Surya Raya, 2004), p. 62.

${ }^{38}$ Sukron Kamil, Syariah Islam dan HAM: Dampak Perda Sayriah Terhadap Kebebasan Sipil, Hak-Hak Perempuan dan Non-Muslim (Jakarta: Center for Study of Religion and Culture UIN Jakarta, 2007), p. 17. 
traditional law or laws that apply in certain social communities which can be categorized as non-neutral laws. ${ }^{39}$ The material of ijtihad as the basis for making laws can be categorized as indicators of nationalism, because the function of ijtihad is not only limited to religious issues and Muslims, but also in the process of building a nation. Figh as a product of ijtihad is inseparable from the whole series of Islamic teachings. However, Islamic law which has become an integral part of national law in Indonesia, needs to be directed to the al-taqnin cycle (legal period) to meet the needs of Muslims as Indonesian citizens. ${ }^{40}$

Based on this, PAI learning materials have proven their contribution in explaining the harmonization of the relationship between Pancasila and the Qur'an. Although the balance between the two portions of the material has not yet been realized, this is a natural thing. Considering the dominance of the discussion on the Koran is because PAI realizes that the position of religion is higher than ideology. In addition, in the Rohis learning material, the explanation of the harmonization of the relationship between Pancasila and the Al-Quran has not become a priority material compared to the needs of students for daily religious studies, such as prayer, fasting and other worship. ${ }^{41}$ It is quite difficult to see any indicators of nationalism from this perspective. Spiritual material that is oriented to personality and moral development takes more Al-Quran and Hadith as a source of material by using references in the form of Al-Quran verses, Arab'in Hadith and Sirah Nabawiyyah. ${ }^{42}$ From this it can be concluded

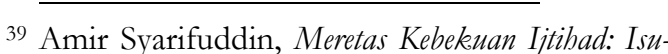
Isu Penting Hukum Islam Kontemporer di Indonesia (Jakarta: Ciputat Press, 2005), p. 24.

40 Ali Yafie, Menggagas Figh Sosial: dari Soal Lingkungan Hidup, Asuransi Hingga Ukhumwah, Cet ke 3 (Bandung: Mizan, 1995), p. 121-122.

41 Informan A, (Rohis Mentor) Interview, \{Wednesday, 14 August 2011\}.

42 Informan B, (Rohis Mentor) Interview, \{Wednesday, 14 August 2011\}. that Rohis learning in terms of inculcating elements of nationalism, through socializing the relationship between Pancasila and the Qur'an does not have a negative influence on PAI's efforts. However, Rohis' material which is still 'reluctant' to look at Pancasila has also not made a positive contribution in supporting PAI learning and its efforts to increase students' sense of nationalism.

\section{Islamic Learning Methods in Efforts to Grow Nationalism and Islamic Values}

\section{Humanistic-Emosional Approach}

The humanistic-emotional approach starts from the idea of humanizing humans. ${ }^{43}$ In relation to Islamic religious learning, a humanistic approach should be based on humanistic-religious theories that are guided by the universal human values of the Qur'an and Hadith. That is, the humanistic-religious approach aims to humanize humans in several forms; 1) providing opportunities for students to develop their potential tools as optimal as possible to function as a means of solving life problems, developing science and technology and human culture and developing an attitude of faith and piety to God, 2) developing some divine attributes (fitrah) in an integrated manner and actualized in everyday life, both individually and socially, 3) guiding and directing humans to be able to carry out the mandate from Allah, both as servants of God and caliphs on earth. ${ }^{44}$ While the emotional approach is an approach that considers the intellectual development of students important, where emotions are very influential on intellectual stimulation. ${ }^{45}$ So, the humanistic-emotional approach is the teacher's effort to arouse students' sense of humanity

$43 \overline{\text { Peter Roberts, Education, Literacy and }}$ Humanization: Exploring the Work of Paulo Freire (Westport: Bergin dan Garvey, 2000), p. 18.

44 Muhaimin, Pengembangan Kurikulum PAI di Sekolah, Madrasah dan Perguruan Tinggi (Jakarta: Rajawali Pers, 2009), p. 159.

${ }^{45}$ Hamzah B.Uno, Orientasi Baru dalam Psikologi Pembelajaran (Jakarta: Bumi Aksara, 2008), p. 116. 
and empathy in understanding and analyzing learning materials.

Table 1. Humanistic-Emosional Approach

\begin{tabular}{|c|c|c|c|c|c|c|}
\hline \multirow{2}{*}{ Statement } & \multicolumn{3}{|c|}{ Score } & & \multirow[t]{2}{*}{ Total } & \multirow[t]{2}{*}{$\%$} \\
\hline & SS & $\mathrm{S}$ & KK & TP & & \\
\hline $\begin{array}{l}\text { Teacher touched } \\
\text { me when he } \\
\text { explained social } \\
\text { problems }\end{array}$ & 28 & 39 & 10 & 0 & 77 & 77 \\
\hline $\begin{array}{l}\text { PAI learning } \\
\text { encourages me to } \\
\text { love each other } \\
\text { among fellow } \\
\text { citizens }\end{array}$ & 24 & 33 & 16 & 0 & 73 & 73 \\
\hline Average & 26 & 36 & 13 & 0 & 75 & 75 \\
\hline $\begin{array}{l}\text { Rohis' activities } \\
\text { motivate me to } \\
\text { foster a sense of } \\
\text { equality and } \\
\text { brotherhood with } \\
\text { fellow human } \\
\text { beings including } \\
\text { non-Muslims }\end{array}$ & 40 & 27 & 12 & 0 & 79 & 79 \\
\hline $\begin{array}{l}\text { Rohis activities } \\
\text { foster my } \\
\text { empathy for } \\
\text { humanitarian } \\
\text { issues that } \\
\text { distinguish } \\
\text { religion and } \\
\text { culture }\end{array}$ & 36 & 30 & 10 & 1 & 77 & 77 \\
\hline Average & 38 & $\begin{array}{l}28, \\
5\end{array}$ & 11 & 0,5 & 78 & 78 \\
\hline
\end{tabular}

Source: Variable Questionnaire of PAI and Rohis Learning Method for PAI Students Rohis Members

The results of the research in table 1 using the questionnaire method showed that the humanistic-emotional approach was often used by PAI teachers in the learning process with a percentage of $75 \%$ and had a positive impact on the psychology of students. This approach succeeded in awakening students' feelings of compassion for the problems and difficulties of others, as well as exercising their affection for all citizens, without discriminating against religion, race and culture. Meanwhile, spiritual learning presented with a humanisticemotional approach reached $78 \%$. Its implementation is dominated by the motivation of a sense of equality and brotherhood regardless of religious background. Another form of implementation is also by fostering a sense of empathy for humanitarian problems. This type of approach is applied in Rohis learning by referring to the tarbiyah approach of the Ikhwan al-Muslimin such as; a personal approach, prioritizing emotional ties and a soft and subtle way, as well as tying the ties of ukhuwah and usrah (kinship) systems. ${ }^{46}$

\section{Socio-Cultural Approach}

The socio-cultural approach serves to explore religious teachings from the aspect of social relations in the midst of cultural and religious diversity. The socio-cultural aspect is filled with the values of equality, justice, freedom or independence, and on the other hand rejects discrimination and hostility.

Table 2. Sosio-Cultural Approach

\begin{tabular}{|c|c|c|c|c|c|c|}
\hline \multirow{2}{*}{ Statement } & \multicolumn{3}{|c|}{ Score } & & \multirow[t]{2}{*}{ Ttl } & \multirow[t]{2}{*}{$\%$} \\
\hline & SS & S & KK & TP & & \\
\hline $\begin{array}{l}\text { The teacher } \\
\text { encouraged me } \\
\text { to accept the } \\
\text { existence of } \\
\text { religious and } \\
\text { cultural } \\
\text { differences in a } \\
\text { society }\end{array}$ & 32 & 36 & 8 & 1 & 77 & 77 \\
\hline $\begin{array}{l}\text { The teacher gives } \\
\text { an understanding } \\
\text { that a Muslim } \\
\text { must socialize } \\
\text { with the } \\
\text { community } \\
\text { without } \\
\text { distinguishing } \\
\text { religion and } \\
\text { culture }\end{array}$ & 28 & 48 & & 0 & 80 & 80 \\
\hline $\begin{array}{l}\text { PAI learning } \\
\text { motivates to } \\
\text { avoid hostility } \\
\text { and disputes } \\
\text { between fellow } \\
\text { students and } \\
\text { society }\end{array}$ & 40 & 27 & 12 & 0 & 79 & 79 \\
\hline Averages & $\begin{array}{l}33 \\
3\end{array}$ & 37 & 8 & 0,3 & 78,6 & 78,6 \\
\hline $\begin{array}{l}\text { Rohis treats } \\
\text { students who } \\
\text { wear headscarves } \\
\text { and those who } \\
\text { don't with the } \\
\text { same treatment }\end{array}$ & 56 & 18 & 8 & 1 & 83 & 83 \\
\hline $\begin{array}{l}\text { Spiritual activities } \\
\text { train me to open } \\
\text { myself up in }\end{array}$ & 56 & 30 & 2 & 0 & 88 & 88 \\
\hline
\end{tabular}

\footnotetext{
${ }^{46}$ Farha Ciciek.
} 


\begin{tabular}{|c|c|c|c|c|c|c|}
\hline \multirow{2}{*}{ Statement } & \multicolumn{3}{|c|}{ Score } & & \multirow[t]{2}{*}{ Ttl } & \multirow[t]{2}{*}{$\%$} \\
\hline & SS & $\mathrm{S}$ & KK & TP & & \\
\hline $\begin{array}{l}\text { social } \\
\text { interactions }\end{array}$ & & & & & & \\
\hline $\begin{array}{l}\text { The mentor } \\
\text { motivates me to } \\
\text { respect people's } \\
\text { religious and } \\
\text { cultural } \\
\text { differences }\end{array}$ & 28 & 30 & 14 & 1 & 73 & 73 \\
\hline $\begin{array}{l}\text { My mentor } \\
\text { encouraged me } \\
\text { not to think } \\
\text { narrowly about } \\
\text { Islam because } \\
\text { Islam is a } \\
\text { blessing for the } \\
\text { universe }\end{array}$ & 68 & 18 & 2 & 1 & 89 & 89 \\
\hline Averages & 52 & 24 & 6,5 & 0,75 & 83,3 & 83,3 \\
\hline
\end{tabular}

Based on table 2 explain that the application of this approach in PAI learning succeeded in having a positive impact in the form of the formation of characters who respect equality as human beings, acceptance of plurality and peace, which reached $83.3 \%$. This approach is also applied in spiritual learning. Based on the results of the questionnaire of Rohis members, this approach was successful in having an impact on the personality formation of Rohis members with a figure of $78.6 \%$.

From these results, it should be noted that theological and philosophical approaches are mandatory approaches that must be used in understanding religious teachings as God's revelation. However, when this approach is combined with a humanistic-emotional and socio-cultural approach, it will produce a balanced understanding of living as a Muslim as well as being a good citizen or known as a religious-nationalism character.

The approaches above should be the initial concepts that are embedded in the minds of teachers. The initial concept is then used as the basis for designing a learning method. Basically, learning methods in PAI subjects are very diverse. The results of this study indicate several methods that are classified as frequently practiced in PAI classes, namely: 1) Leatoring Method, which is carried out with good material mastery from PAI teachers, and does not turn off students' critical and creative power. The following are the results of the questionnaire that can explain the above data in more detail in Table 3:

Table 3. Leatoring Method

\begin{tabular}{|c|c|c|c|c|c|c|}
\hline \multirow{2}{*}{ Statement } & \multicolumn{3}{|c|}{ Scores } & & \multirow{2}{*}{$\begin{array}{l}\text { Tot } \\
\text { al }\end{array}$} & \multirow[t]{2}{*}{$\%$} \\
\hline & SS & $\mathbf{S}$ & KK & TP & & \\
\hline $\begin{array}{l}\text { The explanation } \\
\text { of the PAI } \\
\text { material shows } \\
\text { the teacher's } \\
\text { broad religious } \\
\text { insight }\end{array}$ & 60 & 27 & 2 & 0 & 89 & 89 \\
\hline $\begin{array}{l}\text { The teacher's } \\
\text { lecture at the } \\
\text { beginning of the } \\
\text { lesson gave me } \\
\text { knowledge about } \\
\text { new things } \\
\text { happening in the } \\
\text { community }\end{array}$ & 24 & 27 & 20 & 0 & 71 & 71 \\
\hline Averages & 42 & 27 & 11 & 0 & 80 & 80 \\
\hline
\end{tabular}

2) Discussion method, with $80.5 \%$ discussion themes referring to the discussion of harmonious relations between/religion and the state, humanity, unity and integrity, plurality, democracy and justice:

Table 4. Discussion Method

\begin{tabular}{|c|c|c|c|c|c|c|}
\hline \multirow{2}{*}{ Statement } & \multicolumn{3}{|c|}{ Scores } & & \multirow{2}{*}{$\begin{array}{c}\text { Tot } \\
\text { al }\end{array}$} & \multirow[t]{2}{*}{$\%$} \\
\hline & SS & $\mathrm{S}$ & KK & TP & & \\
\hline $\begin{array}{l}\text { The teacher } \\
\text { recommends } \\
\text { discussion topics } \\
\text { related to social } \\
\text { problems }\end{array}$ & 40 & 30 & 10 & 0 & 80 & 80 \\
\hline $\begin{array}{l}\text { Teachers practice } \\
\text { the principle of } \\
\text { freedom of } \\
\text { expression in } \\
\text { class discussions }\end{array}$ & 44 & 36 & 4 & 0 & 78 & 78 \\
\hline $\begin{array}{l}\text { In discussions, } \\
\text { the teacher gets } \\
\text { used to } \\
\text { respecting the } \\
\text { opinions of } \\
\text { others }\end{array}$ & 44 & 33 & 6 & 0 & 83 & 83 \\
\hline $\begin{array}{l}\text { The teacher } \\
\text { advises to avoid } \\
\text { inappropriate } \\
\text { words when } \\
\text { discussing } \\
\text { followers of } \\
\text { other religions }\end{array}$ & 36 & 33 & 12 & 0 & 81 & 81 \\
\hline
\end{tabular}




\begin{tabular}{llllllll}
\hline \multirow{2}{*}{ Statement } & \multicolumn{3}{c}{ Scores } & \multicolumn{3}{c}{ Tot } & $\%$ \\
\cline { 2 - 5 } & SS & S & KK & TP & al & \\
\hline and cultures & & & & & & & \\
\hline Averages & 41 & 33 & 8 & 0 & 80,5 & 80,5 \\
\hline
\end{tabular}

3) Problem solving method, which is based on conceptual learning and is contrary to textual learning that is often used in radical Islamic groups:

Table 5. Problem Solving Method

\begin{tabular}{|c|c|c|c|c|c|c|}
\hline \multirow{2}{*}{ Statement } & \multicolumn{3}{|c|}{ Scores } & & \multirow{2}{*}{$\begin{array}{c}\text { Tot } \\
\text { al }\end{array}$} & \multirow[t]{2}{*}{$\%$} \\
\hline & ss & $\mathrm{S}$ & KK & TP & & \\
\hline $\begin{array}{l}\text { The teacher } \\
\text { raises problems } \\
\text { that occur in the } \\
\text { community and } \\
\text { asks students to } \\
\text { find solutions to } \\
\text { the problem }\end{array}$ & 44 & 30 & 8 & 0 & 82 & 82 \\
\hline $\begin{array}{l}\text { The teacher } \\
\text { advocates the } \\
\text { principle of unity } \\
\text { and brotherhood } \\
\text { in finding } \\
\text { solutions to } \\
\text { problems }\end{array}$ & 4 & 18 & 26 & 5 & 53 & 53 \\
\hline Averages & 24 & 24 & 17 & 2,5 & 67,5 & 67,5 \\
\hline
\end{tabular}

In addition, the Rohis learning method shows different characteristics from PAI. In general, the Rohis learning method is divided into three forms; first, the religious lecture method, usually carried out at the beginning or at the end of the mentoring activity and in lecture activities outside of mentoring. Lectures are also sometimes called tabligh which are packaged as attractive as possible.

Second, the more popular discussion method is called mentoring, which is a coaching activity that takes place continuously under the guidance of a mentor. Mentoring is adapted from liqa' which is the tarbiyah tradition of the Ikhwan al-Muslimin. In general, Badrus Zaman describes the approaches applied in this mentoring activity; a) a rational approach for deepening the material, b) an emotional approach to train students' emotional control in living a behavior, and c) an exemplary approach with coaches and mentors as figures who provide examples of behavior. ${ }^{47}$ In addition, in public schools, a peer-to-peer approach has also been developed to make the program more attractive and effective.

Third, non-material methods that include activities both inside and outside school, such as counseling on adolescent problems, Islamic studies, daurah or mabit, rihlah or tafakkur alam, sports, Islamic art exhibitions and so on.

In the various methods used, Rohis' activities are focused on sharing between mentee and their respective mentors. This aims to make Rohis activities a comfortable place to discuss various things about the lives of students. The discussion themes that are often conveyed in mentoring are also very diverse, $72 \%$ of the topics relate to social issues, $60 \%$ about inter-religious conflicts in Indonesia, and $51 \%$ about terrorism. All of these topics were discussed through discussion and applying the principles of democracy and freedom of speech and expression.

In general, the Rohis learning method is more likely to show indications of the cultivation of religious-nationalism values, although it does not explicitly show its tendency to nationalism. However, Rohis is also more protective of fundamentalist and radical ideologies by not restricting its members to certain ideologies, narrow thoughts or certain figures. The activities carried out by Rohis are more concerned with establishing an Islamic personality and elevating the Messenger of Allah as the main characters in religious and daily life. ${ }^{48}$ The

47 Badrus Zaman, 'Pelaksanaan Mentoring Ekstrakurikuler Rohani Islam dalam Meningkatkan Kecerdasan Spiritual Siswa Kelas X di SMA Negeri 3 Boyolali Th. Ajaran 2015/2016', Jurnal Inspirasi, 1.1 (2017), 139-54.

48 Informan A, (Rohis Mentor) Interview, \{Wednesday, 14 August 2011)'. 
uniqueness of this learning method cannot be ignored, because it can be one of the main factors for Rohis' contribution in optimizing the cognitive and affective aspects of students which in turn will have an impact on increasing PAI learning achievement in schools. ${ }^{49}$

\section{Islamic Religious Learning and Insan Kamil Character Building}

In the course of its history, Islamic education has proven that its main goal is the formation of a complete human character. This can be seen from how Islamic education makes Rasulullah SAW the main role model in thinking and behaving. Character education in Islam emphasizes that the role of religious teachings is the basis for character development both theoretically and practically. Good and correct understanding of religious teachings as well as a strong commitment to carry out these teachings guarantee to form noble character. On the other hand, if religious teachings are only practiced at the level of formality, this role will not work..$^{50}$ The highest peak of a character in the view of Islam is the character of Insan Kamil. The concept of our human being describes the ideal human being termed by Yusuf Zaidan as a man of shalih. ${ }^{51}$

Shalih makes the concept of insan kamil in Islam unique and special because it makes religious teachings its main source, so that every character formed will always stand on a strong spiritual foundation. Likewise, the nationalist character that is instilled in the souls of students through proper religious education will grow a nationalist character based on religious teachings. This is in line with the concept of human resources which consists of

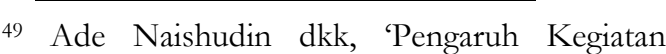
Ekstrakurilkuler Rohani Islam (ROHIS) Terhadap Perstasi Belajar Siswa Pada Mata Pelajaran PAI', Thoriqatuna: Jurmal Pendidikan Islam, 3.2 (2020), 128-36.

50 Muhdar HM, 'Pendidikan Karakter Menuju SDM Paripurna', Al-Ulum, 13.1 (2013), 118.

51 Yusuf Zaidan, Al-Fiker Al-Shufi inda 'Abd AlKarim Al-Jili (Beirut: Dar al-Nahdlah al-'Arabiyah, 1988), p. 23. two inseparable elements, namely, physical and spiritual. ${ }^{52}$ One of the imbalances will eliminate human potential itself, on the other hand the balance between physical and spiritual potential which is full of religious values will make humans reach a complete degree.

Based on this theory, the formation of nationalist character through institutions should take a new step by returning to the basics of religious teachings, especially Islam. Islamic religious learning held in public schools should be a learning model that makes a major contribution to this effort. This idea can be the initial movement in revitalizing religious education as an agent of character formation, it can also counteract various oblique issues about the minimal role of religion in the development of nationalism values, or even lead to accusations of being a breeding ground for radicalism.

As obtained from the results of this study, which shows that the internalization of the value of nationalism through religious learning in PAI and Rohis subject classes has formed a new and more comprehensive model of character formation. The basis of religious teachings makes the nationalist character becomes nationalist-religious character. This religion-based character is ultimately expected to give birth to pious humans, insan kamil or plenary human resources as a manifestation of divine values on earth.

\section{Conclusion}

This study shows that Islamic religious learning held in public schools is colored by two influences that both play a role in forming student character, namely Islamic teachings and nationalism. These two influences run in an integrated manner in the Islamic religious learning process, both in the material aspect and in the method aspect. In addition, the

\footnotetext{
52 Anggan Suhandana, Pendidikan Nasional Sebagai Instrumen Pengembangan SDM (Bandung: Mizan, 1997), p. 151.
} 
learning process is not dominated by the indoctrinative lecture method but instead maximizes the interactive method between educators and students. Character education is also focused on shaping the personality that will be applied in everyday life, and avoiding the inclusion of political ideologies in his studies. Thus, this learning process is expected to be the main forum in giving birth to a generation of insan kamil with strong nationalist-religious characters.

\section{References}

\section{Books}

Anggan Suhandana, Pendidikan Nasional Sebagai Instrumen Pengembangan SDM (Bandung: Mizan, 1997)

Arikunto, Suharsimi, Prosedur Penelitian: Suatu Pendekatan Praktik (Jakarta: Rineka Cipta, 2006)

B.Uno, Hamzah, Orientasi Baru dalam Psikologi Pembelajaran (Jakarta: Bumi Aksara, 2008)

Balitbang Agama Semarang, Transmisi NilaiNilai Keagamaan Melalui Organisasi Rohis (Orientasi Politik dan Sikap Toleransi Peserta Didik) (Semarang: Balitbang Agama, 2017)

Blaycock, L., Secondary Religion Education and Citizenship: Towards an Open Frontier (Birmingham: Christian Education Publications, 2002)

Christoper Winch dan John GIngell, Philosophy of Education: The Key Concepts, 2nd edn (New York: Routledge, 2008)

Departemen Pendidikan Nasional, UndangUndang Sistem Pendidikan Nasional No. 20 Tabun 2003 (Jakarta: Departemen Pendidikan Nasional, 2003)

Effendy, Bahtiar, Islam dan Negara: Transformasi Pemikiran dan Praktik Politik Islam di Indonesia (Jakarta: Paramadina, 1998)

Farha Ciciek, Kaum Muda dan Regenerasi' Gerakan Fundamentalis di Indonesia (Jakarta: Laporam Penelitian RAHIMA, 2008)
Furchan, Arief, Developing Pancasilaist Muslims: Islamic Religious Education in Public Schools in Indonesia (Jakarta: Logos Wacana Ilmu, 2002)

Tim, GBPP Pendidikan Agama Islam (Jakarta: Depag, 1994)

Grimmitt, M., Pedagogies of Religious Education (Great Wakering: McCrimmon, 2000)

Hargreaves, David, The Mosaic of Learning: Schools and Teachers for the Next Century (London: Demos, 1994)

Healy, Julia Overton, 'Learning Enhancement', in Learning and Teaching, ed. by Joseph Zajda (Australia: James Nicholas Publisher, 2006)

J. Mark Halstead dan Mark A, Citizenship and Moral Education (New York: Routledge, 2006)

Jackson, Robert, 'Citizenship as Replacement for Religious Education or Religious Education as Complementary to Citizenship Education', in International Perspective on Citizenship, Education and Religion Diversity, ed. by Robert Jackson (London: Routledge Falmer, 2003)

Kamil, Sukron, Syariah Islam dan HAM: Dampak Perda Sayriah terhadap Kebebasan Sipil, Hak-Hak Perempuan dan Non-Muslim (Jakarta: Center for Study of Religion and Culture UIN Jakarta, 2007)

Karim, M. Abdul, Menggali Muatan Pancasila dalam Perspektif Islam (Yogyakarta: Surya Raya, 2004)

M. Sukardjo dan Ukim Komaruddin, Landasan Pendidikan: Konsep dan Aplikasinya (Jakarta: Rajawali Press, 2009)

Machmudi, Yon, Partai Keadilan Sejabtera: Wajah Baru Islam Politik Indonesia (Bandung: Harakatuna Publishing, 2005)

Moch. Lukluil Maknun dkk, Literatur Keagamaan Robis dan Wacana Intoleransi, I (Jakarta Pusat: Litbangdiklat Press, 2018)

Moleong, Lexy J., Metodologi Penelitian Kualitatif (Bandung: Remaja Rosdakarya, 2000)

Muhaimin, Paradigma Pendidikan Islam: Upaya Mengefektifkean PAI di Sekolah (Bandung: 
Remaja Rosdakarya, 2004)

-, Pengembangan Kurikulum PAI di Sekolah, Madrasah dan Perguruan Tinggi Jakarta: Rajawali Pers, 2009)

Rais, M. Amien, Taubid Sosial; Formula Menggempur Kesenjangan (Bandung: Mizan, 1998)

Roberts, Peter, Education, Literacy and Humanization: Exploring the Work of Paulo Freire (Westport: Bergin dan Garvey, 2000)

Ruslan, Utsman 'Abd al-Mu'iz, Tarbiyah Siyasiyah: Pendidikan Politik Ikbwanul Muslimin, ed. by Saifuddin Abu Sayyid (Solo: Era Intermedia, 2000)

S. Kirbiantoro dan Dody Rudianto, Pergulatan Ideologi Partai Politik Indonesia: Nasionalisme, Islamisme, Komunisme dan Militerisme Jakarta: Badan Politik Pertahanan dan Keamanan Dewan Pimpinan Pusat PAN, 2006)

Sirozi, Muhammad, Politik Pendidikan: Dinamika Hubungan antara Kepentingan Kekuasaan dan Praktik Penyelenggaraan Pendidikan (Jakarta: Raja Grafindo Persada, 2007)

Smith, Anthony D., Nasionalisme: Teori, Ideologi dan Sejarah (Jakarta: Erlangga, 2003)

Syarifuddin, Amir, Meretas Kebekuan Ijtihad: IsuIsu Penting Hukum Islam Kontemporer di Indonesia (Jakarta: Ciputat Press, 2005)

Tilaar, H.A.R., Multikulturalisme: TantanganTantangan Global Masa Depan dalam Transformasi Pendidikan Nasional (Jakarta: PT Grasindo, 2004)

Wiggin, Gladys A., Education and Nationalism: An Historical Interpretation at American Education (New York: McGraw-Hill Book Company Inc., 1962)

Yafie, Ali, Menggagas Fiqh Sosial: dari Soal Lingkungan Hidup, Asuransi Hingga Ukhuwwah, Cet ke 3 (Bandung: Mizan, 1995)
Zaidan, Yusuf, Al-Fiker Al-Shufi inda 'Abd AlKarim Al-jili (Beirut: Dar al-Nahdlah al'Arabiyah, 1988)

\section{Journals}

Ade Naishudin dkk, 'Pengaruh Kegiatan Ekstrakurilkuler Rohani Islam (Rohis) Terhadap Perstasi Belajar Siswa Pada Mata Pelajaran PAI', Thoriqatuna: Jurmal Pendidikan Islam, 3.2 (2020), 128-36

Gutierez, Robert, 'Spiritual Foundation for Civic Education', Taboo, 9.1 (2005), 69

HM, Muhdar, 'Pendidikan Karakter Menuju SDM Paripurna', Al-Ulum, 13.1 (2013), 118

Mukhlisin, M. Nurul, 'Pengembangan PAI Berbasis Pendidikan Karakter', Inovatif, 1.2 (2015), 38-56

Nanggala, Agil, 'Citizenship Education as a Democracy Learning for Students in Higher Education', Intrenational Journal of Education and Curriculum Application, 3.1 (2020), 69-80

Zafi, Ashif Az, Nilai Nasionalisme Kebangsaan Aktivis Rohis', Belajea: Jurnal Pendidikan Islam, 2.2 (2019), 165-84

Zaman, Badrus, 'Pelaksanaan Mentoring Ekstrakurikuler Rohani Islam dalam Meningkatkan Kecerdasan Spiritual Siswa Kelas X di SMA Negeri 3 Boyolali Th. Ajaran 2015/2016', Jurnal Inspirasi, 1.1 (2017), 139-54

\section{Interview}

Informan A, (Rohis Mentor) Interview, \{Wednesday, 14 August 2011\}.

Informan B, (Rohis Mentor) Interview, \{Wednesday, 14 August 2011\}. 